\title{
Peningkatan Pemahaman PUIL 2000 dan Perhitungan Iluminasi pada Museum Deli Serdang
}

\author{
Rahmaniar $^{1 \bowtie}$, Siti Anisah $^{2}$, Agus Junaidi ${ }^{3}$ \\ Teknik Elektro, Universitas Pembangunan Panca Budi, Indonesia ${ }^{1,2}$ \\ Teknik Elektro, Universitas Negeri Medan, Indonesia ${ }^{3}$ \\ E-mail: rahmaniar@dosenpancabudi.ac.id ${ }^{1}$, sitianisah@dosenpancabudi.ac.id ${ }^{2}$, agusjunaidi@unimed.ac.id ${ }^{3}$
}

\begin{abstract}
Abstrak
Museum sebagai satu bagian cagar budaya di kawasan Deli Serdang, Sumatera Utara menjadi objek wisata penting masyarakat sekitar Sumatera Utara. Museum memiliki peran penting dalam mengedukasi masyarakat tentang peristiwa melalui peninggalan sejarah masa lalu dengan benda-benda koleksi dalam bentuk bendabenda seni budaya yang mengandung nilai keindahan estetika dan unik, merupakan penawar bagi para pengunjung yang berwisata. Universitas Pembangunan Panca Budi dan Universitas Negeri Medan melalui kolaborasi kerja sama antar dosen pada kegiatan Pengabdian kepada Masyarakat (Abdimas) mengambil peran bekerjasama dengan pengelola Museum melaksanakan kegiatan implementasi teknologi bidang teknik elektro untuk melakukan penguatan terhadap penggunaan peralatan listrik bagi pengelola gedung budaya. Museum diresmikan sejak tahun 2003, saat ini telah beroperasi 18 tahun, tentu membutuhkan peninjauan kembali terkait kuat penerangan lampu yang sangat menyentuh estetika, kenyamanan dan keamanan kelistrikan ruang gedung dilakukan dengan metode pengukuran menggunakan lux meter. Sedangkan penguatan pemahaman tentang keamanan listrik dilakukan dengan sosialisasi standar PUIL 2000 kepada operator gedung yang mengelola kelistrikan. Kedua metode digunakan dalam kegiatan ABDIMAS tersebut menghasil rata-rata pengukuran kuat penerangan di lantai 1, lantai 2 dan lantai 3 masih memenuhi standar SNI 16 -7062-2004, dan pemahaman operator terkait PUIL 2000 pada bagian sistem kelistrikan tentang instalasi listrik gedung, pada tingkat pemahaman $82,1 \%$ pada katagori baik.
\end{abstract}

Kata kunci: pengabdian kepada masyarakat, PUIL 2000, museum Deli Serdang

\section{Abstract}

The museum as a part of cultural heritage in the Deli Serdang area, North Sumatra, an important tourist attraction for the people around North Sumatra, has an important role in educating the public about events that are relics of the past with collection objects in the form of cultural art objects that contain beauty values. aesthetic and unique is an antidote for visitors who travel. Panca Budi Development University and Medan State University Collaborative collaboration between lecturers in Community Service activities (ABDIMAS) take a role with Museum managers carrying out implementation activities in the field of electrical engineering to increase the use of electrical equipment for Museum managers. The museum, which was founded in 2003, has now been operating for 18 years, of course, related to information related to very beautiful lighting, comfort and security of the building space network, which is carried out using the measurement method using a lux meter, analyzed using the average value of the measurement using a measuring instrument. Meanwhile, strengthening the understanding of electrical safety is carried out by socializing the PUIL 2000 standard to building operators who manage electricity. The two methods used in ABDIMAS activities resulted in the average measurement of lighting strength on the 1st, 2nd and 3rd floors still meeting the standards of SNI 16 7062-2004, and the operator's understanding of PUIL 2000 in the electrical system section on electrical building installations, in the understanding level of $83 \%$ in the good category.

Keywords: community service, PUIL 2000, deli serdang museum

Copyright (c) 2021 Rahmaniar, Siti Anisah, Agus Junaidi

$\triangle$ Corresponding author

Address : Sari Rejo Polonia Medan

Email : rahmaniar@dosen.pancabudi.ac.id

DOI $\quad:$ https://doi.org/10.31004/abdidas.v2i3.326

ISSN 2721-9224 (Media Cetak)

ISSN 2721- 9216 (Media Online) 
647 Peningkatan Pemahaman PUIL 2000 dan Perhitungan Iluminasi pada Museum Deli Serdang Rahmaniar, Siti Anisah, Agus Junaid

DOI: https://doi.org/10.31004/abdidas.v2i3.326

\section{PENDAHULUAN}

Museum secara umum dapat didefenisikan sebagai bangunan cagar budaya yang terdiri dari peninggalan-peninggalan sejarah suatu daerah. Penggeseran defenisi terjadi dari waktu ke waktu terhadap museum, bukan hanya sekedar ruang penyimpanan barang-barang yang bernilai sejarah, sejauh ini keberadaan museum telah menjadi defenisi wisata yang dapat diperhitungkan keberadaannya. Seperti yang dituliskan (Brown \& Mairesse, 2018) dalam pengertian museum melalui peran sosial mengatakan bahwa peranan museum dalam kehidupan bersosial sangat erat kaitannya dengan nilai-nilai museum, partisipasi dan inklusi sosial.

Keberadaan museum di tengah-tengah sosial masyarakat, selain dapat menumbuhkan cagar budaya, dapat juga sebagai pengetahuan geografis, dan objek wisata. Museum yang terdapat pada Kawasan Deli Serdang, seperti yang telah dituliskan oleh Badan Statistik Deli Serdang, bahwa keberadaan Museum Deli Serdang ini di titik koordinat $3^{\circ} 33^{\prime}$ 07.8'LU 9851'59.3'BT, yang dibangun pada tahun 2001 dan pada tanggal 8 September 2018 diresmikan oleh Menteri Pendidikan dan Kebudayaan Republik Indonesia. (Rusmiyati, 2018). Koleksi-koleksi pada museum mencakup ragam budaya yang di antaranya adalah budaya Melayu, budaya Karo, dan budaya Simalungun.

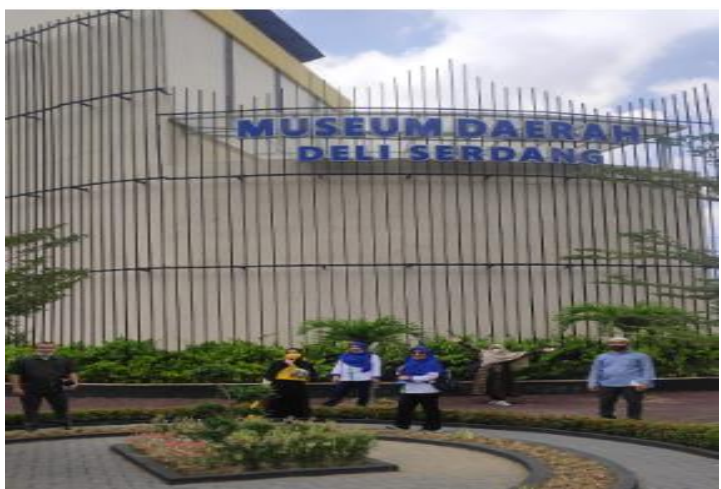

Gambar 1. Museum Daerah Deli Serdang
Bangunan Museum Deli Serdang memiliki konsep yang terinspirasi dari filosofi budaya melayu yaitu "itik pulang petang" memiliki makna kepatuhan serta kebaikan. Bangunan Museum Deli Serdang dengan tiga lantai, di mana pada lantai pertama pemandangan dan informasi-informasi seputar zaman pra sejarah yang terdiri dari beberapa kerajaan di antaranya Kerajaan Kesultanan Melayu Deli dan Kerajaan Kesultanan Serdang.

Menuju lantai dua terdapat koleksi-koleksi dari Putri Hijau dan perjalanan sejarah Putra Melayu dalam memperjuangkan kemerdekaan Republik Indonesia. Pada lantai dua koleksikoleksi Kesultanan Serdang seperti mata uang, pakaian-pakaian adat, alat musik dan prasastiprasasti peninggalan sejarah disuguhkan pada lantai ini. Pada lantai tiga koleksi-koleksi pasca kemerdekaan dan satu ruangan audio video.

Bangunan Museum Deli Serdang dengan tiga lantai, termasuk dalam klasifikasi gedung bertingkat yang besifat sosial dan komersil sehingga memerlukan keamanan dan kenyamanan bagi konsumen atau pengunjung. Salah satu keamanan yang harus diperhatikan adalah distribusi kelistrikan dan kenyamanan penyinaran pada alat-alat cagar budaya yang ditampilkan (Engvang \& Jradi, 2021).

Merujuk PUIL 2000 tentang keamanan dan kenyamanan pemakaian energi listrik pada gedung bertingkat, sosialisasi pemahaman pengamanan dan efesisensi pemakaian listrik pada bangunan Museum Deli Serdang dilakukan. Sistem keamanan dalam penggunaan listrik untuk antisipasi kebakaran dibagi dalam tiga klasifikasi yaitu: klasifikasi preventif, klasifikasi reprensif dan klasifikasi rehabilitatif. Preventif merupakan upaya pencegahan yang diselenggarakan sebelum kejadian kecelakaan dalam hal ini kecelakaan kebakaran, dengan tujuan dapat menekan dan 
648 Peningkatan Pemahaman PUIL 2000 dan Perhitungan Iluminasi pada Museum Deli Serdang Rahmaniar, Siti Anisah, Agus Junaid

DOI: https://doi.org/10.31004/abdidas.v2i3.326

mencegah faktor-faktor yang dapat menyebabkan kecelakaan, antara lain dengan melakukan dan mengadakan sosialisasi pemahaman, pengawasan pada bahan-bahan yang digunakan dan melakukan pelatihan secara terstruktur. (Engvang \& Jradi, 2021).

Kelayakan keamanaan terkait penggunaan kabel pada gedung-gedung bertingkat mengacu pada standar yang tertuang dalam IEC (International Electrotechnical Commission), sebagai batas waktu pemakaian, di mana standarisasi kabel listrik yang telah terpasang memiliki batas waktu penggunaan dari rentang waktu 25 sampai 30 tahun, dikuatkan dengan Peraturan Umum Instalasi Listrik (PUIL) yang mewajibkan dilakukan pengecekan terhadap kabel listrik yang telah terpasang secara regular dengan minimal pengecekan dilakukan pada lima tahun sekali.

Pemakaian energi listrik lainnya adalah penerangan yang umumnya digunakan sebagai pencahayaan pada ruangan dan pada objek-objek yang ditampilkan pada museum. Pencahayaan tentunya memiliki standarisasi sebagaimana yang disampaikan pada keputusan Menteri Kesehatan No. 145 Tahun 2002 menyebutkan bahwa pencahayaan adalah besarnya penyinaran pada suatu objek kerja yang digunakan dalam pelaksanaan aktifitas secara efektif. Dalam pencahayaan dapat terbagi menjadi dua yaitu pencahayaan alami dan pencayaan buatan.

(Soydan \& Engin, 2014) berpendapat tentang hal-hal yang diperlukan dalam pencahayaan bangunan antara lain adalah: komoditas yang berarti kebutuhan yang dipandang dari pengguna cahaya, kekokohan yang memiliki arti pencahayaan yang mengikuti perkembangan teknologi, keindahan yang memiliki arti penciptaan karakter bangunan yang mampu membangkitkan emosi.
Pemanfaatan penerangan kelistrikan yang memenuhi unsur estetika, keandalan serta keamanan menjadi penting bagi bangunan museum, sehingga pengunjung wisata museum akan merasa nyaman dan aman. Dalam hal itu dilakukan kegiatan ABDIMAS yang melibatkan kerjasama dosen lintas perguruan tinggi bersama pengelola Museum Deli Serdang, bertujuan untuk mengimplementasikan Iptek pada masyarakat dalam bentuk sosialisasi dan interaksi langsung, sehingga dapat diperoleh data dan hasil analisis valid untuk penggunaan, perawatan dan pengoperasian sistem kelistrikan di gedung yang secara kontinu memenuhi standar PUIL maupun standar SNI.

\section{METODE}

Museum Deli Serdang merupakan lokasi pengabdian kepada masyarakat yang dipilih dengan cara ditentukan sesuai perencanaan yang disetujui oleh Lembaga Penelitian dan Pengabdian pada Masyarakat (LPPM) UNPAB. Pemilihan didasarkan pada pertimbangan lokasi yang terjangkau oleh kampus dan pertimbangan penting lain seperti, gedung objek vital yang memiliki wawasan tentang sejarah dan budaya Deli Serdang, dimana diketahui bahwa ragam budaya dan sejarah patut untuk dilestarikan dan diperkenalkan kepada setiap generasi.

Kegiatan ABDIMAS ini dilakukan mulai dari perencanaan penyusunan proposal di bulan Januari 2021 sampai pelaporan, di bulan 13-14 Maret 2021 seperti ditunjukkan dalam diagram alur proses gambar 2 . 


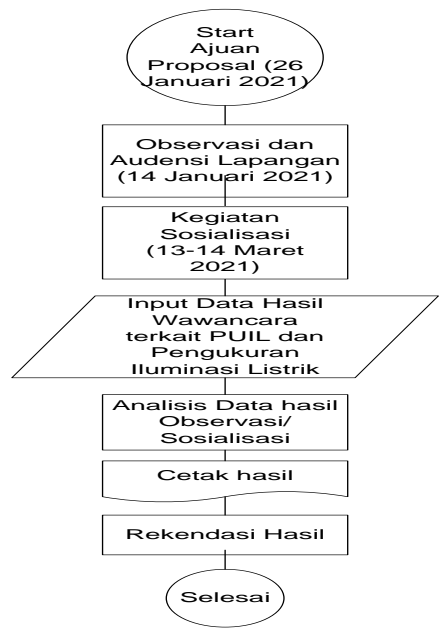

Gambar 2. Alur/Proses Kegiatan

Proses kegiatan ABDIMAS ditunjukkan pada gambar 2, dapat dideskripsikan bahwa dari hasil audiensi ditetapkan sosialisasi ABDIMAS pada tanggal 13 dan 14 Maret 2021. Pada saat sosialisasi tim ABDIMAS melakukan pengukuran beberapa titik sampel lampu penerangan di lantai 1 dan 2, selanjutnya melalui wawancara terkait pemanfaatan listrik dan pengoperasiannya, melalui angket diperoleh data wawancara. Dari proses ini, selanjutnya dilakukan analisis data dan cetak hasil kemudian diberikan rekomendasi. Serangkaian kegiatan ini ABDIMAS ini dimaksud selain terbina hubungan kerjasama perguruan tinggi dengan pemerintah daerah, juga peran dosen yang berkontribusi untuk menjaga aset Gedung Cagar Budaya/Museum Deli Serdang dalam bentuk pengamatan langsung penggunaan kelistrikan yang memenuhi standar yang ditetapkan.

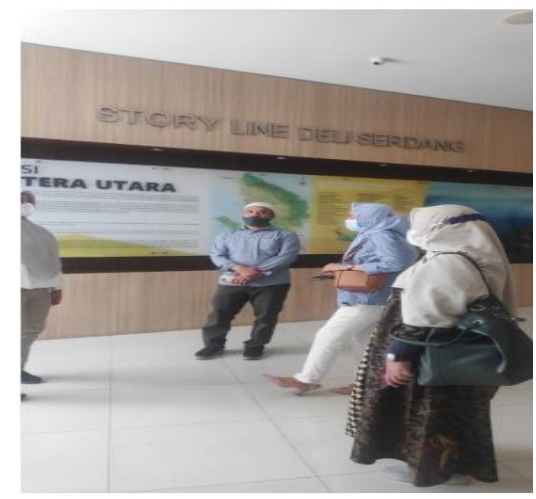

Gambar 3. Diskusi Kondisi Kelistrikan dan

Pencahayaan pada Museum Deli Serdang

\section{HASIL DAN PEMBAHASAN}

Dalam penyampaian sosialisasi ABDIMAS di lapangan terkait pemanfaatan kelistrikan dan penanganan bahaya listrik, dilakukan jejaring pendapat tingkat pemahaman tentang sistem kelistrikan dan penerangan pada pengelola gedung museum. Melalui instrumen angket, diperoleh informasi sebagai berikut:

\begin{tabular}{|c|c|c|c|}
\hline $\begin{array}{c}\text { Aspek } \\
\text { Pendapat }\end{array}$ & Uraian & $\begin{array}{c}\text { Kriteria } \\
\text { Penilaian }\end{array}$ & $\begin{array}{c}\text { Indeks } \\
\text { pemahama } \\
n\end{array}$ \\
\hline \multirow[t]{2}{*}{$\begin{array}{l}\text { 1.Operasion } \\
\text { al Teknis }\end{array}$} & $\begin{array}{l}\text { a. } \\
\text { Penggunaa } \\
\text { n beban } \\
\text { listrik }\end{array}$ & 3 & 0,75 \\
\hline & $\begin{array}{l}\text { b. } \\
\text { Pengoperas } \\
\text { ian } \\
\text { peralatan } \\
\text { listrik }\end{array}$ & 4 & 1 \\
\hline \multirow{2}{*}{$\begin{array}{l}\text { 2.Tindakan } \\
\text { Pengamana } \\
\text { n }\end{array}$} & $\begin{array}{l}\text { a.Pencegah } \\
\text { an }\end{array}$ & 3 & 0,75 \\
\hline & $\begin{array}{l}\text { b.Pertolong } \\
\text { an }\end{array}$ & 3 & 0,75 \\
\hline \multirow[t]{2}{*}{$\begin{array}{l}\text { 3.Bahaya } \\
\text { Listrik }\end{array}$} & $\begin{array}{l}\text { a.Antisipasi } \\
\text { penggunaan } \\
\text { stop kontak } \\
\text { beban } \\
\text { berlebihan }\end{array}$ & 4 & 1 \\
\hline & $\begin{array}{l}\text { b.Penempat } \\
\text { an/ } \\
\text { penyimpan } \\
\text { an } \\
\text { Bahan yang } \\
\text { mudah } \\
\text { terbakar } \\
\text { jauh dari } \\
\text { sumber } \\
\text { lisrik, } \\
\text { seperti stop } \\
\text { kontak dan } \\
\text { switch } \\
\text { lainnya }\end{array}$ & 3 & 0,75 \\
\hline \multicolumn{3}{|c|}{ Index pemahaman index pemahaman } & 0,821 \\
\hline \multicolumn{3}{|c|}{$\begin{array}{l}\text { Tingkat rata-rata Deskriptif presentatif } \\
\text { pemahaman dasar standar PUIL (terkait } \\
\text { keamaan pengoperasion sistem } \\
\text { kelistrikan bangunan gedung }\end{array}$} & $\begin{array}{l}82,1 \% \\
\text { (baik) }\end{array}$ \\
\hline
\end{tabular}

Hasil jejaring pendapat tentang standar PUIL terkait sistem kelistrikan bangunan gedung untuk aspek pengoperasian dan antisipasi bahaya listrik pada kegiatan pengabdian kepada masyarakat yang telah diselenggarakan pada 
650 Peningkatan Pemahaman PUIL 2000 dan Perhitungan Iluminasi pada Museum Deli Serdang Rahmaniar, Siti Anisah, Agus Junaid

DOI: https://doi.org/10.31004/abdidas.v2i3.326

Museum Deli Serdang tentang instalasi listrik dan pengoperasional yang benar pada kategori baik (indeks pemahaman 0,821) dan lumenasi pencahayaan dari hasil pengujian beberapa sampel pencahayaan ruang dengan perangkat alat lux meter menunjukkan intensitas penerangan gedung sesuai standar SNI 16 -7062-2004.

Dalam upaya meningkatkan serta menjaga tingkat pemahaman operator secara berkelanjutan, pelaksanaan kegiatan ABDIMAS ini diproses dengan tahapan diagram alur proses yang ditunjukkan pada gambar 4 .

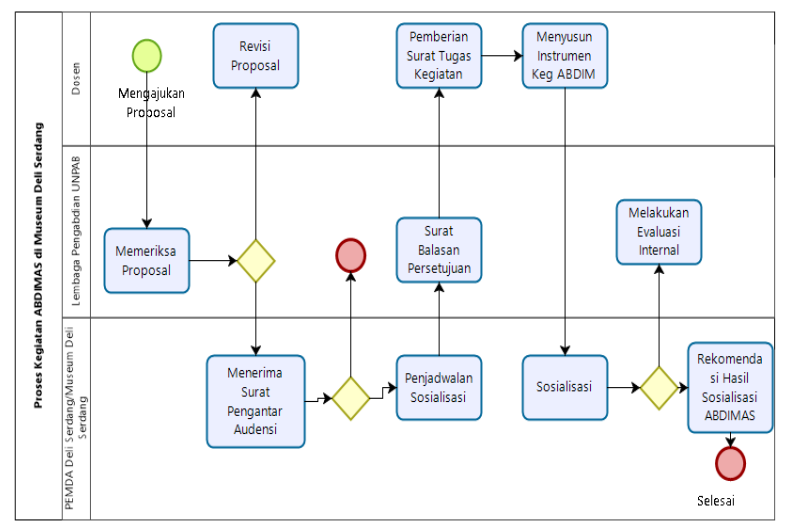

Gambar 4. Alur Proses Kegiatan ABDIMAS

Sebagaimana yang didapat di lapangan melalui performa pencahayaan yang dilihat langsung oleh tim pengabdian didapat bahwa:

1. Masih terdapat kekurangpahaman tentang instalasi kelistrikan pada beberapa pegawai pada Museum Deli Serdang, terutama pada pegawai yang bertugas sebagai pemandu pengunjung, sehingga dengan adanya penguatan tentang instalasi yang sesuai standar PUIL 2000, para pegawai yang bertugas lebih mudah memahami tentang standar tersebut.

2. Masih terdapat kekurangpahaman tentang bahaya kelistrikan dan penghematan penggunaan listrik pada beberapa pegawai pada museum, sehingga dengan adanya penguatan tentang standar PUIL 2000 para pegawai yang ada di Museum Deli Serdang lebih memahami bahaya yang dapat terjadi serta upaya yang dapat dilakukan dalam penghematan penggunaan tenaga listrik.

3. Pencahayaan pada objek-objek yang berada pada display galeri masih kurang efektif, sehingga menimbulkan pantulan yang mengurangi kenyamanan penglihatan untuk pengunjung museum. Dengan adanya pendalaman pemahaman tentang standar lumen dan pencahayaan maka pihak museum akan meninjau ulang tentang pemakaian lampu bantu.

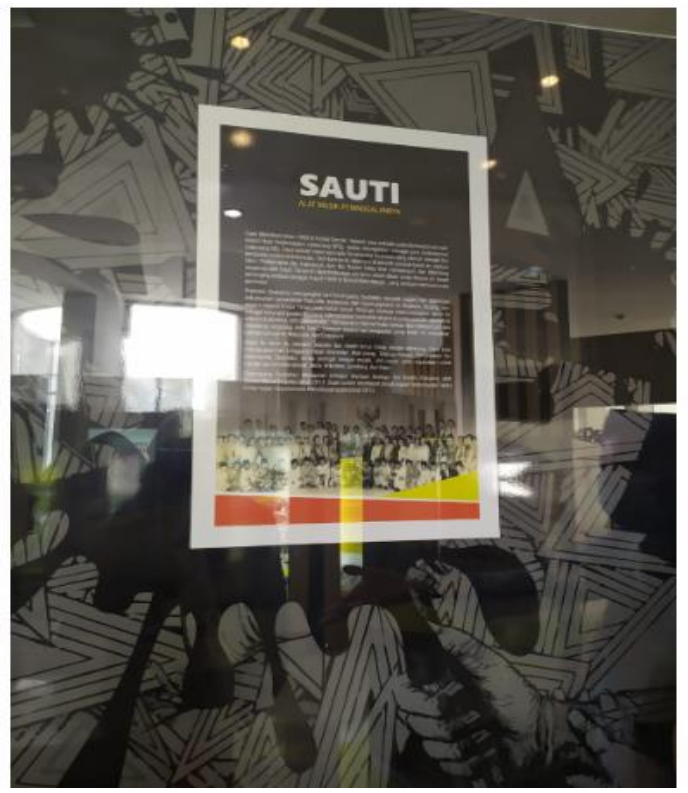

Gambar 5. Contoh Pencahayaan pada Display Museum

4. Pencahayaan dan lumen pada tangga menuju ruang display dapat dikombinasikan dengan pencahayaan yang datang dari luar ruangan dengan memperhatikan penggunaan cat ruangan tangga pada Museum Deli Serdang.

Peningkatan konsumsi energi pada bangunan harus melalui konservasi energi bangunan tersebut, untuk mendukung pembangunan energi nasional (Cong et al., 2015), sehingga dengan pengadaan pengabdian kepada 
651 Peningkatan Pemahaman PUIL 2000 dan Perhitungan Iluminasi pada Museum Deli Serdang Rahmaniar, Siti Anisah, Agus Junaid

DOI: https://doi.org/10.31004/abdidas.v2i3.326

masyarakat di Museum Deli Serdang merupakan salah satu upaya yang dapat dilakukan dalam mendukung pembangunan energi nasional dan meningkatkan pemahaman tentang standar PUIL serta perhitungan lumen pada gedung Museum Deli Serdang.

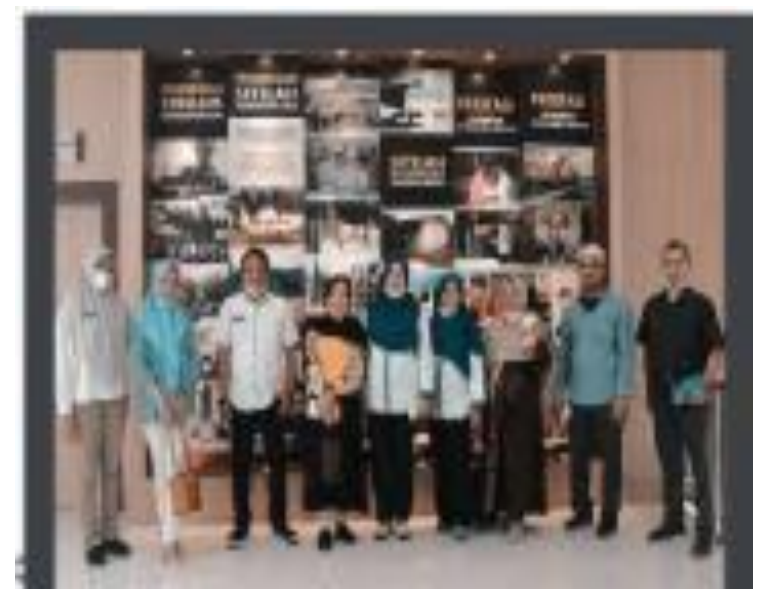

Gambar 6. Kunjungan Tim Pengabdian ke

Museum Deli Serdang

\section{SIMPULAN}

Kunjungan pengabdian kepada masyarakat pada Museum Deli Serdang berjalan dengan lancar dan sukses. Tersampaikannya informasi -informasi penting tentang standar pemakaian listrik dapat diterima dan dipahami dengan baik, sehingga diharapkan Museum Deli Serdang dapat lebih optimal dalam mengembangkan dan melestarikan.

\section{UCAPAN TERIMA KASIH}

Terima kasih diucapkan kepada Universitas Pembangunan Pancabudi yang telah memberikan dukungan kepada tim pengabdian dalam bentuk penyediaan alat transportasi. Terima Kasih diucapkan kepada seluruh pegawai Museum Deli Serdang yang telah menyambut dan meluangkan waktu dan kesempatan kepada tim pengabdian kepada masyarakat.

\section{DAFTAR PUSTAKA}

Badan Standarisasi Nasional. (2000). Persyaratan Umum Instalasi Listrik 2000 (PUIL 2000). DirJen Ketenagalistrikan, 2000(Puil), 1-133.

Brown, K., \& Mairesse, F. (2018). The definition of the museum through its social role. Curator: The Museum Journal, 61(4), 525539. https://doi.org/10.1111/cura.12276

Cong, C., Xiangzhao, M., Xing, L., Xiaohu, Y., Wangyang, H., \& Liwen, J. (2015). Energy Analysis of Relics Museum Buildings. Energy Procedia, 75, 1809-1818. https://doi.org/10.1016/j.egypro.2015.07.150

Engvang, J. A., \& Jradi, M. (2021). Auditing and design evaluation of building automation and control systems based on eu.bac system audit - Danish case study. Energy and Built Environment, 2(1), 34-44. https://doi.org/10.1016/j.enbenv.2020.06.002

Rusmiyati. (2018). Katalog Museum Indonesia 1. Direktorat Pelestarian Cagar Budaya dan Permuseuman Direktorat Jenderal Kebudayaan Kementerian Pendidikan dan Kebudayaan.

Soydan, Y., \& Engin, T. (2014). Lighting building interiors requiring lighting at day times by conveying daylight. ReasearchGate. 